DOI: 10.19195/2353-8546.6.3

\author{
EPP ANNUS \\ Estonian Literature Museum (Tartu, Estonia) \\ Ohio State University (Columbus, OH, USA)
}

\title{
Traumatic body, word, and otherness: Refugees and deportations in the 1940s Estonian Soviet Socialist Republic
}

\begin{abstract}
Traumatic body, word, and otherness: Refugees and deportations in the 1940s Estonian Soviet Socialist Republic. This essay analyses some instances of Estonian life-writing in order to investigate the question of collective trauma in the Soviet-era Baltics, and especially in Estonia. I suggest that it is precisely the combination of wounded body, word and otherness that forms the basis of collective, or national trauma. In working through or acting out the traumatic as a repetitive event, the affective charge in the wounded body will find its expression through the unconditional rejection of the Other. This intimate liaison between the negative affective charge that is experienced in the body and the Other that is figured in the imagination is disseminated in discursive form. The link between the national Other and one's bodily vulnerability is established in a way that resists rationalization: for those who lived through the trauma of deportations, the Other becomes transfixed in a structure of trauma in a way that cannot be negotiated.
\end{abstract}

Keywords: trauma, body, otherness, Baltic states, deportations

Травматическое тело, слово и другое: беженцы и депортации в 1940-х годах в Эстонской Советской Социалистической Республике. В статье анализируются некоторые примеры эстонских биографических писаний, чтобы исследовать вопрос о коллективной травме в странах Прибалтики в советскую эпоху, особенно в Эстонии. Полагается, что именно комбинация раненого тела, слова и другой природы составляет основу коллективной или национальной травмы. При работе или разыгрывании травматического как повторяющегося события, эмоциональный заряд в раненом теле находит свое выражение через безусловное отклонение Другого. Эта интимная связь между отрицательным аффективным зарядом, который испытывается в теле и Другом, фигурирующим в воображении, распространяется в дискурсивной форме. Национальная связь с Другим и 
физиологической уязвимостью устанавливается таким образом, который не подлежит рационализации: для тех, кто пережил травму депортаций, Другое становится запертым в структуре травмы таким образом, что оно не обсуждается.

Ключевые слова: травма, тело, инаковость, Прибалтика, депортации

March 24, 1949. Two girls in the dark of night are hurrying along a muddy road. Every now and again the sounds of approaching trucks force them to jump from the road, continuing their flight only after the trucks have passed. They walk about twenty kilometres that night, in deep darkness, from their grandmother's house to their mother's, a distance they have never crossed on foot before - their father used to have a car, after all. Yet it is not the distance or the frightening sounds of passing trucks that weighs most heavily on their minds. This is the night of deportations in the Baltics, an effort by the Soviet colonial power to crush local resistance, an effort to destroy the local support base for opposition fighters hiding in the forests and to silence resisting voices. Alltogether that night 95,000 people are being rounded up from their homes in Latvia, Lithuania and Estonia, 8422 trucks are used for this occasion (and additional horse-drawn wagons), to move the deportees into 4437 railway freight cars, which would then head to Amur, Irkutsk, Krasnoyarsk, Novosibirsk, Omsk and Tomsk regions in Russia. An hour to pack and off you go, had been the terms announced at their grandmother's house. They are sending us to our deaths, I will not take anything, their uncle had responded. The women had started packing even so - a sewing mashine, a cuckoo clock from the wall, warm clothes, some food - a mix of symbolically and materially necessary things that were thrown together in a rushed and chaotic manner. The girls had been sent home. Yet what if there was no one waiting for them at home?

I have heard this story of darkness, trucks, and terrifying anxiety many times from my mother, the youngest of the two girls. This journey through the night was surely a traumatic experience for her, something that haunted her throughout her life. During the same night, more than hundred thousand Balts participated in the event of the deportations. For many, this experience shook their existence in a way that would continue weigh on them in the decades to come.

This essay investigates the configuration of collective trauma in the Soviet-era Baltics. How does the singular experience of a traumatic event change into a collective, shared experience? Why do some personal traumas get 'translated' into collective trauma, while some others remain at only a personal level? How does the wounded body speak out and cover the traumatic with the chain of words? I suggest that in either working through or acting out ${ }^{1}$ the traumatic as a repetitive event, the affective charge in the wounded body will find its expression through the unconditional rejection of the

${ }^{1}$ H. Strods and M. Kott, "The file on Operation 'Priboi.' A re-assessment of the mass deportations of 1949”, Journal of Baltic Studies 2002, vol. 33, no. 1, pp. 17-22. 
other. This intimate liaison between the negative affective charge that is experienced in the body and the other that is figured in the imagination is disseminated in a discursive form. By "the other" I mean here the imaginary cause of trauma, the figure that the subject imagines to have been responsible for the traumatic event in question.

I suggest that it is precisely the combination of wounded body, word, and otherness that forms the basis of collective, or national trauma. In case of collective trauma it is a question of the other that needs to be addressed, in order to step out of the field of the traumatic.

From an abundant collection of Baltic life-stories dealing with post-war traumatic experiences, I will investigate two instances that come from Estonia: a short personal recollection published in 2013 in the Estonian literary journal Looming, and a diary entry from 1947. I will then move on to discuss my terms: body, word, and otherness, in more detail, drawing there primarily on Cathy Caruth's work. Finally, I will return to the role of the other in the traumatic imaginary and outline links between national trauma and decolonial processes in the late 1980s Estonia.

Looking at the Soviet-era Baltic experience, my starting point is trauma as a personal, psychic event. In its bodily immediacy, trauma does not, properly speaking, befall a nation: instead, it befalls a person in his or her singularity. "Trauma as a mode of being violently halts the flow of time, fractures the self, and punctures memory and language"2, writes Gabriele Schwab. However, if a traumatic event strikes a significant proportion of a community and thereby comes to reverberate within its discourses (or else haunt its silences), these personal traumas can accumulate into what can be loosely called a collective trauma. According to this model, collective trauma is like a snowball, in which verbal linkages tie together many singular experiences.

Yet there are certainly different models of collective trauma. Take the suppression of Warsaw uprising, for example - this tragedy was, from the onset, experienced at the communal level and shared in the here-and-now of the event: such are traumatic events which are collective at their core. Such a traumatic event functioned according to a model of an avalanche, not a snowball - these were massive, powerful events that befell and buried many at the same time.

This paper looks at the first, "snowball" model of collective trauma: the one that is experienced not as something shared, but rather something that underlines the vulnerability and solitude of the human being, in the face of an incomprehensible, overwhelming event. This singular experience will then, through shared discourse, accumulate or metastasize into collective imaginaries. Just as a traumatic experience will become part of the traumatic subject's identity, so will collective trauma become

2 Dominick LaCapra makes a distinction between "working through" and "acting out": while working through trauma, "one is able to distinguish between past and present and to recognize something as having happened to one (or one's people) back then which is related to, but not identical to here and now." "In acting out the past is performatively regenerated or relived as if it were fully present rather than represented in memory and inscription, and it hauntingly returns as the repressed." D. LaCapra, Writing History, Writing Trauma, Baltimore 2001, p. 66, 70. 
part of collective identity. This process of narrative accretion happens similarily in both the snowball and avalanche models; here, the question is not whether the initial event befell an individual or a group of individuals, but rather how strongly the experience resonated in the rest of the community. Certainly, in the strictest sense of the term, only the avalanche-model presents a case of collective trauma as a case of bodily shock experienced simultaneously by many.

What is needed for an event or a series of events to be considered a collective trauma? Why do some personal traumas, even if they are experienced by many, still not accumulate into a national trauma? In the wake of works by Freud and Cathy Caruth, trauma is here understood as an overwhelming, powerful, horrifying event that befalls a human being with such intensity that it defies signification and thus remains haunting.

\section{The story of Ruth}

Our story of Ruth (born in 1928), takes place in August, 1945. The Soviet Union had annexed the Baltic states in 1940, after the Molotov-Ribbentrop pact, signed between Hitler's Germany and Stalin's Soviet Union, had agreed upon their respective shares of a conquered and divided-up Eastern Europe. From 1941-1944, Estonia had been under German occupation; in 1944, the Red Army had reconquered these territories. By 1945, the Baltics were officially under Soviet rule, though in Estonia the post-war years are often called the 'post-Estonian time' (järel-Eesti aeg): the old social structures were as-yet still in place, people lived with the naive expectation of an intervention from the West and looked forward to the re-establishment of independence in the near future. Here is what Ruth tells of her experience, as 17-year old school girl on her way back to Tallinn after a summer full of work on the farms:

Oli 1945. aasta augustikuu. Olin koolivaheaja veetnud Virumaal onude ja tädide taludes koos pererahvaga maatööd tehes. [...] Minu püüdlikkust rukkivihkude sidumisel „premeeriti” toiduainetega. See oli väga oluline, sest linnas kulges elu nälja piiril. [...] Ema tuli mulle järele, sest üksinda poleks ma jaksanud kaasapandud kraami ja oma suveriideid koju kanda. Pimedal augustiõhtul seisime Sompa jaamas, mõlemal käed pakke täis, ja seal oli väga palju teisigi rongiootajaid. Tollal oli tõesti pime, sest normaalne elektrivarustus polnud veel taastatud. Ainult jaama sees oli nõrka valgust, väljas ei midagi. Rongid käisid ebakorrapäraselt ja harva ning jaamast öeldi hoiatavalt, et peatus kestab ainult ühe minuti. Lõpuks saabus rong, mis niigi oli rahvast pungil, ja pealemahtumine paistis küsitav. Peatumisaeg ka väga lühike. Arusaadavalt tekkis tunglemine. Aga vähe sellest - ootamatult hakkas rongiustest platvormile valguma mingeid kampasid, mis tekitas veel suurema segaduse. Sattusin emast lahku ja äkki olid minu ümber mehed, kes mind tõukasid ja pakid käest rebisid. Hädavaevu pääsesin juba liikuma hakkavale rongile. Ema polnud näha, aga arvasin, et ta on mõnest teisest uksest sisse pääsenud. Tallinnas, kuhu rong jõudis varahommikuses hämaruses, ema mahatulijate hulgas ei olnud. Ehmatus ja hirm oli suur.

This was in August, 1945. I had spent my school holidays in Virumaa, on the farms of my uncles and aunts, working the farm together with their families. [...] My diligence in binding rye was rewarded 
with food. This was very important, since life in the city teetered on the brink of famine [...] My mother came to get me, because on my own I would not have been able to carry both the food and my summer clothes. On a dark August night, we stood in Sompa station, both of us carrying many bundles, and there were many other people waiting for the train. It was really dark in these times, because the normal supply of electricity was not yet restored. There were weak lights only inside the station building - nothing outside. Trains came irregularly and we were warned at the station that the train would stop only for one minute. Finally the train arrived, already overcrowded with people, and it seemed doubtful that we would manage to get in, the stopping time being so short. Naturally, there was chaos. But not only that suddenly some gangs emerged from the train doors and the chaos became even greater. I was separated from my mother and was suddenly surrounded by men, who pushed me and tore the packages from my hands. I barely got onto the already-moving train. My mother was nowhere to be seen, but I trusted that she got in from some other door. When the train reached Tallinn in the early hours of the day, my mother was not among the passengers getting off the train. My anxiety and horror were very great ${ }^{3}$.

For Ruth, this experience, though not damaging to her bodily integrity, included both fear and violence, extreme personal disappointment and sense of limitless injustice - the food was, after all, earned through hard work, and was so necessary to sustain life in these difficult times - and all this combined with the horror of losing her mother. Ruth goes on to tell how she later learned that her mother was likewise robbed of her food. Before the arrival of the next train, her mother heard many similar stories of gang robberies in the train stations, and the locals loaned her some money to buy a new ticket. Such robbers were commonly refered as 'bag people'; it was commonly understood that they had come across the border from Russia. This seems to be a likely setting for a collective trauma: many suffering, many others sharing stories about a threat to a general sense of security and well-being. Also, this story posits a clearly defined other-figure, easily distinguishable as arriving from outside of the sphere of national dignity. The other-figure is multilayered: first of all, there is the gang, the men in the darkness, the immediate cause of the violence enacted upon the body. The circulating narratives of similar robberies and the broader context of recently-established Soviet rule 'elevates' the other into a more generalized cultural image and thus supports the construction of the imaginary Other, the Enemy - the figure that in the national imaginaries is tied to the foreign presence, foreign language, and unfamiliar cultural practices - tied to all that entered the country with the Soviet takeover. Yet here is a moment for our second witness to step in: Jaan Roos, born 1888 , documents the same era in his diary.

\section{The story of Jaan}

For nine years, between 1945 and 1954, in the wake of the arrests of many of his colleagues and acquaintances, Jaan Roos hid himself from the Soviet regime and moved about the countryside, staying with friends and relatives, not daring

\footnotetext{
${ }^{3}$ G. Schwab, Haunting Legacies: Violent Histories and Transgenerational Trauma, New York 2010,
} p. 42 . 
to stay long with anybody. All these years, he kept making notes into his diary; he recorded both the rumors and moods of the era and his personal encounters with different people.

Jaan Roos writes in 1947, January 2: "Võrumaal on teatatud, et Eesti piirile läheneb Venemaalt 15000 kotimeest. Inimesed on hirmul." [The word in Võrumaa is that 15,000 bag people are approaching the Estonian border from Russia. People are afraid]" $"$.

1947, January 4, two days later:

Öö veetsin Küti talus. Külm ja selge ilm kestab. Hommikul käis siin üks 14-aastane kotipoiss Pihkva oblastist. Ta räägib sama juttu, mis kõik Venemaalt tulijad, et seal on nälg. Ema töötab tal kolhoosis, isa langes sõjas. Emal on kokku 5 last. Kolhoosis külvati maha vaid veerand põldudest. Kolhoosis on 2 hobust, 2 lehma ja 2 traktorit. Vili kasvas suvel võrdlemisi hea, aga riik ja kolhoosi ülemus võtsid kõik ära. Kolhoosnikutele ei jäänud midagi. Suvel anti töölistele 100 grammi leiba päevas. Nüüd ei anta enam üldse. [...] Nälg olevat üldine. Veebruaris ja märtsis kardetakse rahva üldist nälga suremist.

I spent the night on Küti farm. The cold, clear weather continues. In the morning, a 14-year old bag-boy from the Pskov region visited the farm. He tells the same story as others arriving from Russia that it's famine there. His mother works on the kolkhoz, his father died in the war. The mother has five children altogether. Only a quarter of the fields were sown in the kolkhoz. The kolkhoz has two horses, two cows and two tractors. The grain grew quite well in the summer, but the state and the head of the kolkhoz took everything. Nothing was left over for the kolkhoz workers. In the summer, the workers were given 100 grams of bread per day. Now nothing is given. [...] Hunger is supposedly everywhere. They fear for the general starvation of the population in February and March ${ }^{5}$.

We hear a rumor - 15,000 people approaching from Russia - and the laconic statement: people are afraid ${ }^{6}$. In this way, Jaan Roos provides the other side of Ruth's story: the famine threatening Russia, masses on the move, the desperation of hunger. His detailed account includes neither emotion nor personal judgement; he relays somebody else's story, not his own bodily experience. His laconic style is nevertheless especially telling. Even without a conventional expression of pathos ("oh, what a horrible situation!"), we do indeed sense his compassion. It might well be that his informant - a boy who needed to collect food items for his starving siblings exaggerated the situation in the kolkhoz. What is important here is not exactly how many cows the kolkhoz had, but the act of interaction, of listening to the other and, one assumes, helping, if possible.

Ruth's account, to the contrary, is carried by her desire to make readers feel the greatness of her loss. What dominates here is fear, the feeling of vulnerability, the violence of the situation, her confusion, the impossibility of making clear sense of a tumult in the darkened train station. The traumatic experience is clearly marked as caused by somebody, the figure of the other is presented forcefully as the one who is

${ }^{4}$ R. Mirov, "Hvostov ja kotipoisid”, Looming 2013, no. 6, p. 1454.

5 J. Roos, Läbi punase öö II. 1947. aasta päevik, Tartu 2000, p. 10. Võrumaa is a district in Estonia close to Russian border.

6 Ibid., p. 11. 
responsible, and who cannot be forgiven. This story is written and published in 2013, Ruth, born in 1928, is now 85 years old - and the memory is still vivid in her mind. 68 years have passed, yet it seems that the passing years have not much lessened the intensity of the event. Ruth's text - of which I presented only a fragment - is full of anguish, feelings of hurt, but also, I would say, of hatred. She puts her experience into a political framework: "In the case of Russian bag people," she says, "we are dealing with the violence of the occupying nation toward the occupied nation"7. She calls the attackers 'predators' and reminds the readers that Estonia, especially the north-eastern part where Ruth spent her summer, had also seriously suffered in the war. She mentions that she has written about this story before. By 2013, Ruth's personal trauma has turned into an accusation against the unlawfulness of Soviet rule. For her, the personal and the collective merge together, gang of violent robbers in the dark start to represent the Soviet rule and the new Russian-speaking migrants more generally.

The encounters with bag people did not, in the Estonian cultural imaginary, accumulate to compose a 'collective trauma'. Many people were robbed, and significant cultural changes took place - the ethnic composition of Estonia was changed, villagers started to lock their doors - yet the narrative of the invasion of bag people was, in the common cultural imaginaries, accompanied by its sibling account, recorded by Jaan Roos: the story of somebody else's hunger and misery and one's own capacity or incapacity to help. These two sides of the same phenomenon - the massive, uncontrolled arrival of foreign war refugees, in the context of lost national sovereignty at the hands of that same foreign power, and the great hunger experienced outside Estonian borders - balanced each other out, without turning into a commonly shared narrative of collective trauma. Ruth's trauma remained her own.

In Ruth's story, we can distinguish the basic features of trauma, as theorized by Sigmund Freud ${ }^{8}$ and later by Cathy Caruth ${ }^{9}$. First of all, traumatic experience is one that continues to haunt - this, for Freud, forms the core of the traumatic. It haunts because it exceeds the sphere of cognition: one cannot quite exhaust this experience by speaking out, by sharing it or writing about it. Ruth's anguish and hurt remained vivid even decades later, because what was lost - the earnings of a whole summer's work, the food necessary to sustain life, perhaps her gift, as a 17-year old, to her mother and family — had such immense importance for her, and because the horror of the situation became engrained in her body.

7 What sounds like a folkloric exaggeration was actually not far from reality: in the postwar years, about 20,000 Russian-speaking refugees per year crossed the Estonian border. O. Mertelsmann, "How the Russians turned into the image of the 'National Enemy' of the Estonians", Pro Ethnologia 2005, no. 19 , p. 53.

8 R. Mirov, op. cit., p. 1454.

9 S. Freud, “Jenseits des Lustprinzips”, [in:] Gesammelte Werke. Band 13. Jenseits des Lustprinzips/ Massenpsychologie und Ich-Analyse/Das Ich und das Es, Frankfurt am Main 1999, pp. 1-69. 
Cathy Caruth also emphasizes another aspect of trauma: its connection to narration. Caruth starts her book Unclaimed Experience: Trauma, Narrative and History (1996) with a literary example from the epic Gerusalemme Liberata by Torquato Tasso, a text analysed also by Freud. In this sixteenth century text, the main hero Tancred kills his beloved Clorinda accidently with a sword. Tancred later finds himself in a strange forest and slashes a tree with a sword, "but blood streams from the cut and the voice of Clorinda, whose soul is imprisoned in the tree, is heard complaining that he has wounded his beloved once again"10.

While Freud is interested in the repetition in this story, Caruth draws attention to the voice emerging from the wound. "Tancred's story," suggests Caruth, "represents traumatic experience not only as the enigma of a human agent's repeated and unknowing acts but also as the enigma of the otherness of a human voice that cries out from the wound, a voice that witnesses a truth that Tancred himself cannot fully know"11. For Caruth, trauma is not "the simple illness of a wounded psyche"12. Instead, "it is always the story of a wound that cries out, that addresses us in the attempt to tell us of a reality or truth that is otherwise not available"13.

Caruth's emphasis on "crying out," on the effort to communicate, speaks especially to the situation of a national trauma. In the case of a national trauma, we are dealing with a bodily, physical, traumatic event, perhaps a series or a sequence of events, experienced by a significant part of the population and then shared with others in different narrative formats, perhaps extending discursively down to the next generations. This event has to be "narratable." Not a single story of war-time rape is found in the corpus of life-stories that forms the basis of the research included in this article ${ }^{14}$; while it is true that silences will also sometimes speak, they can do little to shape the fabric of shared cultural imaginaries.

National trauma, then, carries elements of both narratable story and also that bodily excess that is resistant to reasoning and thus continues to haunt. In the 1940s Baltic states, now under Soviet colonial rule ${ }^{15}$, deportations of tens of thousands of people ${ }^{16}$ were experienced by many as traumatic, and also offered easily narratable material, with many circulating versions of the same basic pattern - a night-time knock on the door, one hour to pack, the ride in the trucks to the train stations, the separation of men from the rest of the families (when food had been packed into a

10 C. Caruth, Unclaimed Experience: Trauma, Narrative and History, Baltimore and London 1996. Trauma studies has by now grown into a huge and varied field of inquiry.

11 Ibid., p. 2.

12 Ibid., p. 3.

13 Ibid., p. 4.

14 Ibid.

15 This research is based on material collected from a variety of published and unpublished sources, altogether about 200 life stories.

16 This article cannot offer a closer exploration of colonial features of the Soviet rule in the Baltics. On this topic, see E. Annus, Soviet Postcolonial Studies: A View from the Western Borderlands, London and New York forthcoming 2017. 
joint bundle, this traveled with only one side of the family), and then the horrific weeks in train cars designed for animal transportation, followed by diseases, deaths, or years of hard work in unfamiliar parts of the Soviet empire. The traumatic emerges where the rational discourse reaches its limit, and with stories of deportations, one steps rather easily over to the side of the non-rational. Deportations were certainly traumatic - one cannot rationally digest the demand to back one's whole life, within one hour, into a maximum of two bundles, and to leave one's whole life behind. Already numbers defy rationalization: the youngest deportee from Estonia was Anne, three days old, from Hiiumaa island, who was deported together with her two year old brother and 22-year old mother; and the oldest deportee was 95-year old Maria from Abja district; among the deportees were 1785 minors without parents to support them ${ }^{17}$. There was a strong sense of repetition involved: the first wave of deportations in the Baltics took place in 1941, quite soon after the annexation of the Baltic states; and the rumours about new deportations started to circulate right away in 1944, after the reestablishment of Soviet rule - the next wave of deportations took place over the years 1948, 1949 and 1951. Even though an effort was made to act secretly, still this massive movement of peoples, and the preparations for it, were well visible also for those who stayed. Many escaped home and hid; Ruth tells how on the deportation night of March 25, 1949, she and her two classmates were staying over the night at her relatives' apartment, listening attentively to the voices from the street - both hers and her classmates' family had decided to spread out this night and to send kids into different 'safe' apartments, to limit the chances of finding them to a minimum ${ }^{18}$.

National trauma draws a connecting link between a bodily trauma and the other, and thus constructs and consolidates the image of a national enemy in a way that exceeds rational explanation and becomes deeply engrained in traumatized bodies. Ruth calls her robbers 'occupiers', as if these people had a political agenda; she transforms the robbers in the train station into a generalized political figure of the other, now understood at the level of cultural imaginaries. The personal is translated into the collective, yet the imaginary other still carries the charge of the singular, material encounter with the robbers in the train station. The bodily anguish finds expression in the unconditional denial of the other.

In Torquato Tasso's story, Tancred himself had been the source of his sufferings; in Soviet-era traumatology, one can easily point to the other as the source of trauma. In this situation, the traumatic enigma can be expressed as the unbelievable crudeness of another human being: one cannot talk about the story of deportations without the particular figure of the enemy, the one who gives orders, the one who

17 About 200,000 people altogether were deported from the Baltic states during the Stalin era. T. Tannberg, "Hilisstalinistlik Eesti NSV," [in:] S. Vahtre (eds.), Eesti ajalugu VI. Vabadussõjast taasiseseisvumiseni, Tartu 2005, p. 274. The population of the three Baltic states together was then somewhat over five million.

18 H. Strods and M. Kott, op. cit., p. 20. 
counts the arrested, or the one who makes sure that the letter in a hand stretched out from a train car will not reach another hand ${ }^{19}$. The link between the national other - a generalized image that is tied to concrete experiences - and one's bodily vulnerability is established in a way that resists rationalization. For those who lived through the trauma of deportations, the other - call it the occupier, the colonizer, the communist, or just more generally Soviet rule as such - becomes transfixed in a structure of trauma in a way that cannot be negotiated.

Without the framework of trauma-theory, one cannot make sense of the ethnic tensions in 1980s-2000s Latvia and Estonia. One especially cannot make sense of the decisions made in 1991, when the newly independent states established their ungenerous policies towards Russian-speaking Soviet-era settlers. These policies are part of the story of a national trauma; one cannot keep politics of the other separated from the hauntings of wounded bodies.

In order to escape the pathological, unproductive circulation of cultural traumatology, one needs to dismantle the figure of the other as the core of the Soviet-era traumatism. Yet how to dismantle the traumatic? By 2017, time has come to help: Ruth's generation, though partially still alive, has ceased to be active in policy-making. Post-traumatic generations still carry on the narratives of hurt and pain, but not the unbreakable connection between the wounded body and the figure of the other, the imaginary cause of trauma. The traumatic connection between body, word, and otherness can finally loosen up and give way to more productive relationships between the narrated word, the bodily experience of being in the world, and the presence of other human beings around us.

\section{Bibliography}

Annus, E. 2017. Soviet Postcolonial Studies: A View from the Western Borderlands. London-New York: Routledge.

Caruth, C. 1996. Unclaimed Experience: Trauma, Narrative and History. Baltimore-London: John Hopkins University Press.

Freud, S. 1999. "Jenseits Des Lustprinzips". In Gesammelte Werke. Band 13. Jenseits Des Lustprinzips/ Massenpsychologie Und Ich-Analyse/Das Ich Und Das Es. Frankfurt am Main: Fischer Taschenbuch Verlag. 1-69.

LaCapra, D. 2001. Writing History, Writing Trauma. Baltimore: John Hopkins University Press.

Mertelsmann, O. 2005. "How the Russians turned into the image of the 'National Enemy' of the Estonians.” Pro Ethnologia 19. 43-58.

Mirov, R. 2004. “Nõmme Roheliste Mändide All: Meenutusi Kulno Süvalepa Luuleraamatu Puhul.” Looming 12. 1881-1890.

Mirov, R. 2013. "Hvostov Ja Kotipoisid." Looming 10. 1454-1455.

Roos, J. 2000. Läbi Punase Öö II. 1947. Aasta Päevik. Tartu: Eesti Kirjanduse Selts.

19 R. Mirov, "Nõmme roheliste mändide all: Meenutusi Kulno Süvalepa luuleraamatu puhul", Looming 2004, no. 12, p. 1887. 
Schwab, G. 2010. Haunting Legacies: Violent Histories and Transgenerational Trauma. New York: Columbia University Press.

Simmermann, L. 2003. “Leonore Simmermann. Sünniaasta 1921.” In R. Hinrikus (eds.). Eesti Rahva Elulood. I Osa. Elu Eesti ENSV-S. Tallinn: Tänapäev. 239-247.

Strods, H. and Kott. M. "The File on Operation 'Priboi'. A Re-Assessment of the Mass Deportations of 1949." Journal of Baltic Studies 33. no. 1. 2002. 1-36.

Tannberg, T. 2005. "Hilisstalinistlik Eesti NSV." In S. Vahtre (eds.). Eesti Ajalugu VI. Vabadussõjast Taasiseseisvumiseni. Tartu: Ilmamaa. 271-287.

Przyjęto do druku/Accepted for publication: 5.05.2017 